\title{
Detection of Isolated Diffuse Cutaneous and Subcutaneous Metastasis of Breast Cancer on FDG-PET/CT
}

\author{
Meme Kanserli Olguda Izole Diffüz Deri-Deri Altı Metastazının FDG-PET/BT ile Tespiti
}

\author{
Müge Öner Tamam1, Özge Vural Topuz1, Tuğba Rezan Ekmekçi2, Gülçin Kamalı3, Mehmet Mülazımoğlu1 \\ IOkmeydanı Training and Research Hospital, Clinic of Nuclear Medicine, Istanbul, Turkey \\ 2 Memorial Hospital, Clinic of Dermatology, Istanbul, Turkey \\ ${ }^{3} \mathrm{Okmeydanı}$ Training and Research Hospital, Clinic of Pathology, Istanbul, Turkey
}

\begin{abstract}
Cutaneous metastasis from internal malignancies are rare with a reported incidence between $0.7 \%$ and $10 \%$. The most common tumor that metastasize to the skin is breast cancer. We present a 53-year-old woman with a history of bilateral breast cancer who underwent FDG-PET/CT for re-staging, which demonstrated isolated cutaneous and subcutaneous chest wall metastases. Histopathologic verification confirmed invasive ductal carcinoma invasion of the dermis and the lymphatic vessels.

Key words: Carcinoma ductal breast, fluorodeoxyglucose F-18, positron-emission tomography and computed tomography, metastasis
\end{abstract}

Conflicts of Interest: The authors reported no conflict of interest related to this article.

\begin{abstract}
Özet
iç organ malignitelerinin deri metastazları nadir olup sıklığı \%0,7 ve \%10 arasındadır. Deri metastazının yaygın olarak meme kanserinde olduğu kabul edilir. Sunduğumuz olguda; bilateral meme kanserli 53 yaşındaki kadın hastaya yeniden evreleme için uygulanan FDG-PET/BT ile, izole deri-deri altı, göğüs duvarı metastazı gösterildi. Bu lezyonların invaziv duktal karsinomun deri ve lenfatiklere invazyonu olduğu histopatolojik olarak doğrulandı.

Anahtar kelimeler: Duktal meme kanseri, fluorodeoksiglukoz F-18, pozitron emisyon tomografisi ve bilgisayarlı tomografi, metastaz
\end{abstract}

Çıkar Çatışması: Yazarlar bu makale ile ilgili olarak herhangi bir çıkar çatışması bildirmemiştir.

\section{Introduction}

Cutaneous metastases from internal malignancies are rare with a reported incidence between $0.7 \%$ and $10 \%(1,2)$. Among all malignancies, the highest incidence of cutaneous metastasis is seen in advanced breast cancer $(3,4)$. Cutaneous metastasis can occur either by lymphatic or hematogenous spread, and is most commonly seen in the head-neck regions and the trunk $(3,5)$.

18F-fluoro-2-deoxyglucose positron emission tomography/computed tomography (FDG-PET/CT) is useful in defining the extent of metastatic disease $(6,7,8)$. Herein, we present isolated cutaneous and subcutaneous chest wall metastasis without other distant organ metastasis that were demonstrated with FDG-PET/CT.

Address for Correspondence: Müge Öner Tamam MD, Okmeydanı Training and Research Hospital, Clinic of Nuclear Medicine, İstanbul, Turkey Phone: +90 2122217777 E-mail: mugeoner@yahoo.com Received: 31.01.2013 Accepted: 19.09.2013 


\section{Case Report}

A 53 year-old woman with bilateral invasive ductal carcinoma of the breast has been treated by modified radical mastectomy-lymph node dissection and chemoradiotherapy. Two years later, she presented with cutaneous lesions. On inspection, clear, erythematous and sharply demarcated irregular lesions were visualized on the left anterior and posterior chest wall and left shoulder (Figure 1a). There were focal vesiculobullous plaques, and palpable small nodules scattered throughout the left anterior chest wall (Figure 1b). 18F-fluoro-2-deoxyglucose positron emission tomography/computed tomography (FDG-PET/CT) (Siemens Biograph 6, Chicago, USA) imaging was applied for restaging, with the suspicion of metastasis from the previous carcinoma. After 7 hours of fasting, with a serum glucose level of $108 \mathrm{mg} / \mathrm{dL}$, the patient was injected with $370 \mathrm{MBq}(10 \mathrm{mCi})$ of F-18 FDG intravenously. Transaxial, sagittal, coronal FDG-PET (Figure 2a) and fused FDG-PET/CT (Figure $2 \mathrm{~b}$ ) images demonstrated mildly increased diffuse F-18 FDG uptake (the maximum standardized uptake value (SUVmax): 11.9) on the cutaneous thickening site and subcutaneous fatty tissues of the anterior, left and left posterior side of the chest wall without evidence of disseminated disease at other sites (Figure 2). Histopathologic evaluation verified invasive ductal carcinoma invasion of the dermis and the lymphatic vessels (Figure 3).

\section{Literature Review and Discussion}

Breast cancer remains the most common type of cancer in women (6). FDG-PET/CT is widely used for detecting local recurrence and local/distant lymph node or organ metastasis in patients with breast cancer. It is a highly sensitive and specific test for identifying distant metastasis especially in patients with breast cancer who had negative conventional imaging results for distant metastasis $(6,7)$.

The most common sites of distant metastasis in breast cancer are bone, lung, liver and brain. Cutaneous metastasis
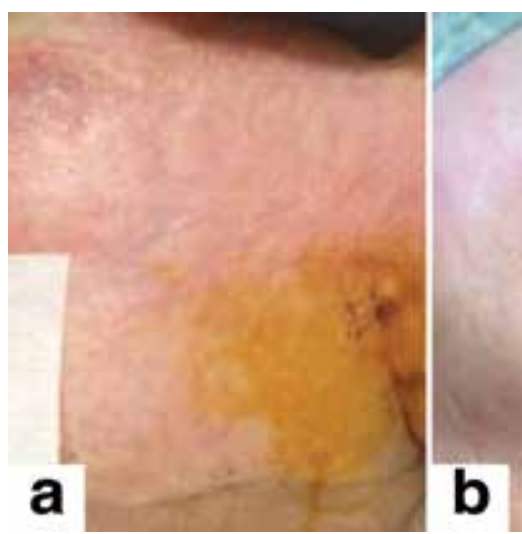

Figure 1. Indurated diffuse erythema, purpura (a) and scattered vesiculobullous plaque (b) on the chest wall. is an unusual site. It can occur either via lymphatic or hematogenous spread, and is commonly seen in the head and neck regions, as well as the trunk and extremities $(3,5,9,10)$. The most common site of metastasis is reported as the chest, which was involved in $28.4 \%$ of metastatic lesions $(3,11)$.

Subcutaneous metastasis of certain malignant diseases such as gastric, colon, esophageal, lung, kidney, bladder and uterine cancer have been previously detected with PET/CT $(12,13,14,15,16)$.

Diagnosis of cutaneous metastasis is based on clinical history, radiology images and histopathologic examination. FDG-PET/CT is an accurate modality in assessing recurrence of breast cancer, and in detecting distant metastasis. It

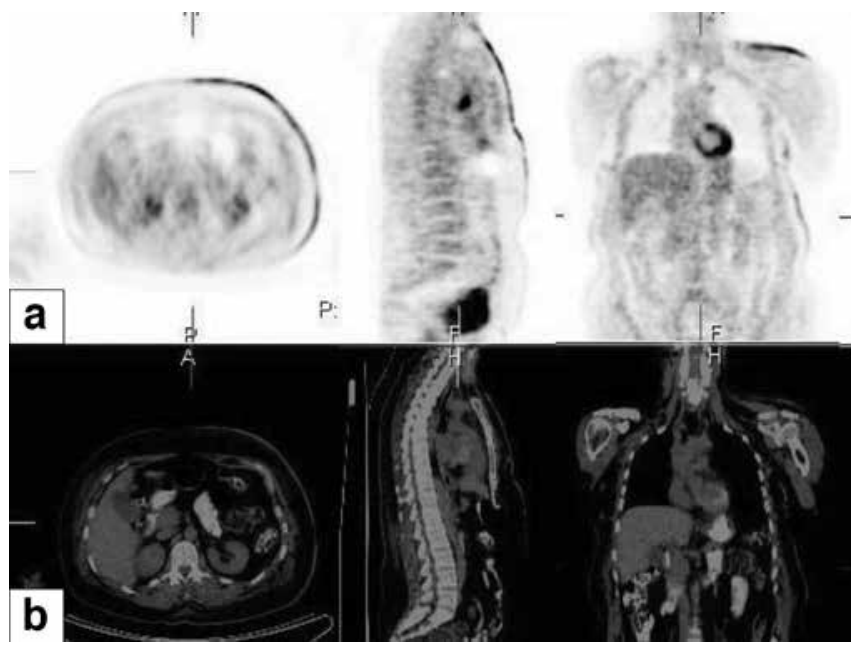

Figure 2. Transaxial, sagittal, coronal FDG-PET (a) and fused FDG-PET/CT (b) images demonstrated mildly increased diffuse F-18 FDG uptake (SUVmax: 11.9) on the cutaneous thickening and subcutaneous fatty tissues of the anterior, left and left posterior side of the chest wall without evidence of disseminated disease at other sites

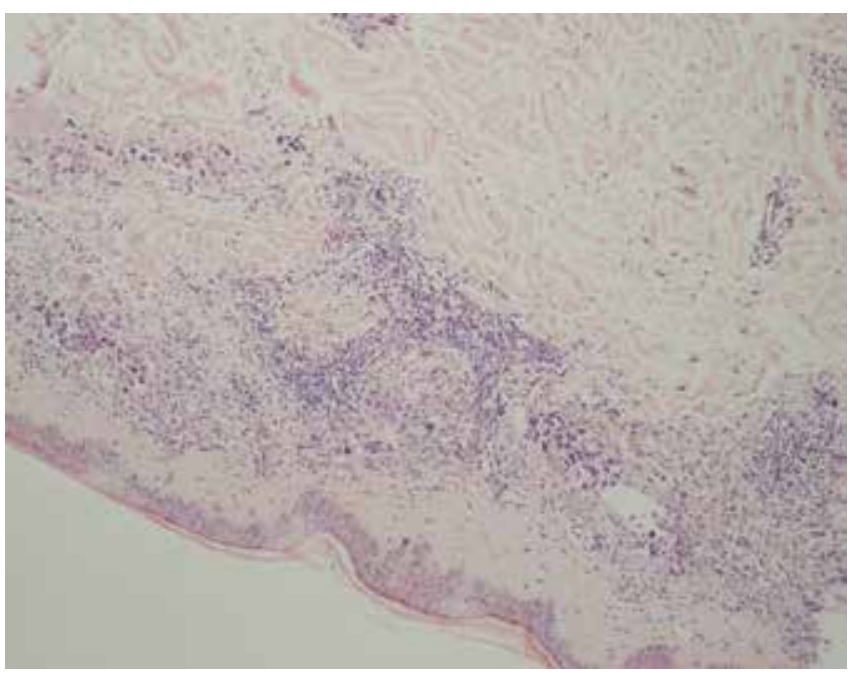

Figure 3. Biopsy showed widespread infiltration of the dermis and lymphatic vessels with mitotic figures by carcinoma (Hematoxylin and eosin, $x 100$ ) 
has higher sensitivity than other conventional methods in terms of detecting skin and soft tissue metastasis. It has a significant impact on the choice of treatment and management $(8,10)$.

Isolated cutaneous-subcutaneous metastases from breast cancer detected with FDG-PET/CT have been rarely reported in the literature. FDG avid skin lesions in a case with breast cancer history should always raise suspicion of skin metastasis and should be evaluated further with histopathologic confirmation.

\section{References}

1. Sariya $D$, Ruth $K$, Adams-McDonnell $R$, Cusack $C, X u X$, Elenitsas R, Seykora J, Pasha T, Zhang P, Baldassano M, Lessin SR, Wu H. Clinicopathologic correlation of cutaneous metastases: experience from a cancer center. Arch Dermatol 2007;143:613-620

2. G Nava, K Greer, J Patterson, KY Lin. Metastatic cutaneous breast carcinoma: A case report and review of the literature. Can J Plast Surg 2009; 17:25-27.

3. Manohar K, Mittal BR, Bhattacharya A, Singh G. Asymptomatic Distant Subcutaneous Metastases Detected by (18)F-FDG-PET/CT in a Patient with Breast Carcinoma. World J Nucl Med 2012;11:24-25.

4. El Khoury J, Khalifeh I, Kibbi AG, Abbas O. Cutaneous metastasis: clinicopathological study of 72 patients from a tertiary care center in Lebanon.Int J Dermatol 2014;53:147-158.

5. Cox SE, Cruz PD Jr. A spectrum of inflammatory metastasis to skin via lymphatics: three cases of carcinoma erysipeloides. J Am Acad Dermatol 1994;30:304-307.
6. Manohar K, Mittal BR, Bhoil A, Bhattacharya A, Singh G. Role of 18F-FDG PET/CT in identifying distant metastatic disease missed by conventional imaging in patients with locally advanced breast cancer. Nucl Med Commun 2013;34:557-561.

7. Blumer SL, Scalcione LR, Ring BN, Johnson R, Motroni B, Katz DS, Yung EY. Cutaneous and subcutaneous imaging on FDG-PET: benign and malignant findings. Clin Nucl Med 2009;34:675-683.

8. Nguyen NC, Chaar BT, Osman MM. Prevalence and patterns of soft tissue metastasis: detection with true whole-body F-18 FDG PET/CT. BMC Med Imaging 2007;7:8.

9. Krathen RA, Orengo IF, Rosen T. Cutaneous metastasis: a metaanalysis of data. South Med J 2003;96:164-167.

10. Borkar S, Pandit-Taskar N. F-18 FDG uptake in cutaneous metastases from breast cancer.Clin Nucl Med 2008;33:488-489.

11. Lookingbill DP, Spangler N, Helm KF. Cutaneous metastases in patients with metastatic carcinoma: a retrospective study of 4020 patients. J Am Acad Dermatol 1993;29:228-236.

12. Hoffmann $M$, Oberhuber $G$, Kletter $K$, Becherer $A$, Raderer $M$. Imaging of cutaneous recurrence of gastric cancer with F-18 FDG positron emission tomography. Clin Nucl Med 2002;27:731-732.

13. Gemmel F, Roosjen H, van der Wijk P, Collins J. Subcutaneous metastasis from an occult esophageal cancer detected by PET-CT. Clin Nucl Med 2008;33:866-867.

14. Hyun IY, Yun MY. FDG uptake in cutaneous and subcutaneous metastases from colorectal adenocarcinoma. Clin Nucl Med 2010;35:93-94.

15. Tamam MO, Mulazimoglu M, Aydin T. Subcutaneous and intramuscular metastases of cervix cancer detected with 18F-fluoro-2deoxyglucose positron emission tomography/computed tomography after the chemoradiation therapy. Rev Esp Med Nucl Imagen Mol 2013;32:128-129.

16. Damron TA, Heiner J. Distant soft tissue metastasis: A series of 30 new patients and 91 cases from the literature. Ann Surg Oncol 2000;7:526-534. 